\title{
CONTRACTUAL RESTRICTIONS ON RIGHT OF BENEFICIARY TO DRAW ON A LETTER OF CREDit; POSSIBLE EXCEPTION TO PRINCIPLE OF AUTONOMY
}

\author{
Hamed Alavi \\ Faculty of Law, Autonomous University of Barcelona, Spain
}

Hamed.alavi@ttu.ee

\begin{abstract}
ALAVI, Hamed. Contractual restrictions on right of beneficiary to draw on a Letter of Credit; possible exception to principle of autonomy. International and Comparative Law Review, 2016, vol. 16, no. 2, pp. 67-86. DOI: 10.1515/iclr2016-0015.
\end{abstract}

\begin{abstract}
Summary: In some circumstances and despite having right to draw under the Letter of Credit, beneficiary agrees in underlying contract that he would not exercise his right before realization of certain conditions stipulated in the contract or any other agreement with applicant. Despite the fact that the instrument itself (documentary letters of credit and bank guarantees) entitles beneficiary for being paid upon presentation of complying documents, making such commitment will impose restrictions on beneficiary within the framework of underlying contract and creates different scenarios that raises respective questions. First scenario would be that beneficiary fulfills his commitments in underlying contract and receives payment under the credit and there will be no dispute between parties. Second scenario is where beneficiary presents complying documents to bank and demands for being paid the amount stipulated in the credit despite existence of an ongoing dispute with applicant regarding his performance in underling contract. Here, it will be a valid question if we ask whether or not breach of such restrictions by beneficiary will influence principle of autonomy? Consecutive question would be, shall the court consider beneficiary's violation of his restrictive commitment in underlying contract as a new exception to principle of autonomy? To put it in different way, where beneficiary of documentary letters of credit or demand guarantee regardless of his awareness from independence of underlying contract from the credit commits in underlying contract to condition which restricts his right to draw on the credit; will he be allowed by court to rely on the principle of autonomy to neglect his commitment in underling contract? In short, should law recognize other exception in addition to fraud which is in accordance with limits imposed by underlying contract on beneficiary's right to draw on the credit? In quest of answering above mentioned questions, this paper will be divided into six main parts. After the introduction, second part will describe nature of documentary leers of credit and principle of autonomy. Third part will analyse the nature of exception while fourth one will look at approach of different jurisdictions to this issue. Fifth part will provide different arguments in favour and against recognition of "underlying contract exception" ${ }^{1}$ and finally last part provides concluding remarks on the subject matter.
\end{abstract}

1 ENONCHONG, Nelson.. The Problem of Abusive Drawing on Demand Guarantees. 
Keywords: Documentary Letters of Credit, Autonomy Principle, Contractual Restrictions on Beneficiary, Exception, Comparative Study.

\section{Introduction}

In the law of letters of credit, fraud is the only exception to the principle of autonomy which has received global recognition. Other exceptions including illegality, nullity, unconscionability and recklessness of beneficiary are all accepted or rejected in different jurisdictions and there is no uniform global position towards their recognition. ${ }^{2}$

In some circumstances and despite having right to draw under the credit, beneficiary agrees in underlying contract that he would not exercise his right before realization of certain conditions stipulated in the contract or any other agreement with applicant. Despite the fact that the instrument itself (documentary letters of credit and bank guarantees) entitles beneficiary for being paid upon presentation of complying documents, making such commitment will impose restrictions on beneficiary within the framework of underlying contract.

Based on the general principles of law, where beneficiary presents complying documents with terms and conditions of the credit, bank is bound to make payment regardless to beneficiary's breach of his commitments within underlying contract. Where there is a dispute between parties to the underlying contract, applicant can claim for damages against beneficiary after reimbursing the bank which has already honoured a complying presentation made by beneficiary. Where applicant considers that collectable damages from beneficiary in a separate action to be insufficient, he might require intervention of court and seek for injunctive relief against beneficiary or bank. Therefore, inclusion of restrictive clauses to beneficiary's right to draw on the credit in underlying contract creates different scenarios and raises respective questions. First scenario would be that beneficiary fulfilled his commitments in underlying contracts, receives payment under the credit and there will be no dispute between parties. Second scenario is where beneficiary presents complying documents to bank and demands for being paid the amount stipulated in the credit despite existence of an ongoing dispute with applicant regarding his performance in underling contract. In second scenario, it will be valid question if we ask whether or not breach of such restrictions by beneficiary will influence principle of autonomy? Consecutive question would be, shall the court consider beneficiary's violation of his restrictive commitment in underlying contract as a new exception to principle of autonomy? To put it in different way, where beneficiary of documentary letters of credit or demand guarantee regardless of his awareness about independence

Lloyd's Maritime and Commercial Law Quarterly, 2007, pp. 83-106.

2 ALAVI. Hamed. Illegality as an exception to principle of autonomy in Documentary Letters of Credit; A comparative approach, Korea University Law Review, 2016, vol. 20, pp. $3-23$. 
of underlying contract from the credit commits in underlying contract to conisations which restrict his right to draw on the credit; will he be allowed by court to rely on principle of autonomy to neglect his commitment in underling contract? In short, should law recognize other exception in addition to fraud which is in accordance with limits imposed by underlying contract on beneficiary's right to draw on the credit?

In practice, problem will arise as courts in different jurisdictions have taken different approaches towards granting injunction against beneficiary and preventing him from drawing on the credit. ${ }^{3}$ Some consider granting injunctive relief against beneficiary and preventing him to claim payment does not affect the independence principle while others are of the contradictory opinion and consider granting any injunction against right of beneficiary to draw on the credit as violating application of independence principle. ${ }^{4}$ The same argument exist among legal scholars where some are of the opinion that granting injunction to prevent beneficiary's demand under the credit dose not affects principle of autonomy while others take the opposite position. ${ }^{5}$ However, everyone agrees that granting injunction against bank's right to pay as a result beneficiary' $s$ complying presentation affects autonomy principle on the basis of public policy concerns. ${ }^{6}$

In quest of answering above mentioned questions, this paper will be divided into six main parts. After the introduction, second part will describe nature of documentary leers of credit and principle of autonomy. Third part will analyse the nature of exception while fourth will look at approach of different jurisdictions to this issue. Fifth part will provide different arguments in favour and against recognition of "underlying contract exception"7 and finally last part provides concluding remarks on the subject matter.

\section{Documentary Letter of Credit and Principle of Autonomy}

At global scale, documentary letters of credit are operating under well recognized set of rules established by International Chamber of Commerce. Uniform Customs and Practices for Documentary Credits (UCP) published in 1933 for the first time and endured many revisions in order to meet requirements of ever evolving nature of international trade. Article 4 and 5 of UCP 600 (current version) define the principle of autonomy as following:

3 ENONCHONG, Nelson. The Independence Principle of Letters of Credits and Demand Guarantees. Oxford: Oxford University Press, 2011, p. 212.

4 MUGASHA, Agasha, Enjoining the beneficiary's claim on a letter of credit or bank guarantee. Journal of business law, 2004, vol. 5, pp. 515-538.

5 Ibid

6 O'DONOVAN James and PHILLIPS, John. The Modern Contract of Guarantee. London: Sweet and Maxwell, 2013, para 13-27.

7 ENONCHONG, Nelson.. The Problem of Abusive Drawing on Demand Guarantees. Lloyd's Maritime and Commercial Law Quarterly, 2007, p. 83. 
"A credit by its nature is a separate transaction from the sale or other contract on which it may be based. Banks are in no way concerned with or bound by such contract, even if any reference whatsoever to it is included in the credit. Consequently, the undertaking of a bank to honour, to negotiate or fulfil any other obligation under the credit is not subject to claims or defences by the applicant resulting from its relationships with the issuing bank or the beneficiary."

"A beneficiary can in no case avail itself of the contractual relationships existing between the banks or between the applicant and the issuing bank. An issuing bank should discourage any attempt by the applicant to include, as an integral part of the credit, copies of the underlying contract, proforma invoice and the like. Finally, banks deals with documents and not with the goods, services or performance to which the document relate."

In the United States of America, applicable rules for governing the operation of letters of credit are defined in article 5 of Unified Commercial Code. In fact, the USA is only country which enjoys statutory law in place for LC operation. Under Article 5-103(d) of UCC the autonomy principle is recognised as following :

"the rights and obligations of an issuer to a beneficiary or a nominated person under a letter of credit are independent of the existence, performance, or nonperformance of the contract or arrangement out of which the letter of credit arises or which underlie it, including contracts or arrangements between the issuer and the applicant and between the applicant and the beneficiary"

Further, article 5-108(f)(1) confirms :

"[a]n issuer is not responsible for the performance or non-performance of the underlying contract, arrangement or transaction"

In practice, courts in different countries show traditional hesitation with interfering in process of LC transaction and enjoining bank or beneficiary to prevent payment under the credit due to existence of the general understanding in favour of absolute application of principle of autonomy. The decision of court in Hamzeh Malas and Sons v British Imex Industries Ltd confirms this position: "[the autonomy principle] imposed upon the banker an absolute obligation to pay, irrespective of any dispute here maybe between the parties as to whether the goods are up to the contract or not". Together with principle of Strict Compliance, Principle of autonomy (also known as principle of independence) is laying down the foundation for successful operation of documentary letters of credit in international trade. ${ }^{10}$ Principle of independence separates obligations of bank to

8 Hamzeh Malas and Sons $v$ British Imex Industries Ltd [1958] 2 QB

9 Ibid, 703

10 ALAVI, Hamed. Mitigating the Risk of Fraud in Documentary Letters of Credit. Baltic Journal of European Studies, 2016, vol. 6, no. 1, pp.139-156. 
pay under the credit from commitments of parties in underlying contract ${ }^{11}$. As a result, it forms an abstract payment undertaking for issuing bank to pay (upon receiving complying presentation from the beneficiary) which is independent from performance of underlying contracts between parties to $\mathrm{it}^{12}$. The main implication of autonomy principle would be as long as beneficiary provides the bank with complying presentation of document stipulated in the credit, his entitlement for being paid by bank will not be affected by failure in fulfilling his obligations within the framework of underlying contract ${ }^{13}$. Therefore, in case of rising any dispute on quality or quantity of goods provided by beneficiary, issuing bank has no other choice rather than honouring complying presentation and leave applicant with sole possibility of looking for remedies in claim for beneficiary's breach of warranty at later stage. However, some scholars are of the opinion that autonomy principle does not exclude buyer's (applicant) interests from being fulfilled. ${ }^{14}$

In contrary with existing image on absolute authority of autonomy principle, courts in different jurisdictions have recognized few conditions which revoke the unconditional payment obligation of bank ${ }^{15}$. Fraud is known as the first recognized exception to principle of autonomy in documentary letters of credit. ${ }^{16}$ It is also submitted that illegal nature of underlying contract would be another exception to principle of authority together with nullity of documents presented by beneficiary ${ }^{17}$. Unconscionable conduct of beneficiary in drawing under the

11 HOROWITZ, Deborah,. Letters of credit and demand guarantees: defences to payment. Oxford: Oxford University Press, 2010.

12 ALAVI, Hamed. Autonomy Principle and Fraud Exception in Documentary Letters of Credit, a Comparative Study between United States and England. International and Comparative Law Review, 2015, vol. 15, no. 2, p. 45; ALAVI, Hamed. Exceptions to Principle of Autonomy in Documentary Letters of Credit; A Comparative View. Actual Problems of Economics and Law, 2016, vol. 10, no. 3, pp. 123-150.

13 FRÍAS GARCÍA, Roberto Luis. The Autonomy Principle of Letters of Credit. Mexican Law Review, 2010, vol. 3, no. 1, p. 4.

14 ELLINGER. Peter; NEO. Dora. The Law and Practice of Documentary Letters of Credit. Oxford: Hart Publishing, 2010, p. 84; BUCKLEY Ross P.; GAO, Xiang. Development of the Fraud Rule in Letter of Credit Law: The Journey So Far and the Road Ahead. University of Pennsylvania Journal of International Law, 2002, vol. 23, no. 4, p. 663.

15 JOHNS, R. J., \& BLODGETT, M. S. . Fairness at the Expense of Commercial Certainty: The International Emergence of Unconscionability and Illegality as Exceptions to the Independence Principle of Letters of Creditand Bank Guarantees. Northern Illinois University Law Review, 2010, vol. 31, no. 2, p. 297.

16 LIPTON, Jacqueline. D. Documentary Credit Law and Practice in the Global Information Age. Fordham International Law Journal, 1998, vol. 22, no. 5, p. 1972.

17 ENONCHONG, Nelson. Effects of Illegality: A Comparative Study in French and. English Law. International \& Comparative Law Quarterly, 1995 vol. 44, no. 1, p. 196, 198-199; REN, John . A nullity exception in letter of credit law? Journal of business law, 2015, no. 1, pp. 1-19; ANTONIOU, Anna Mari. Nullities in Letters of Credit: Extending the Fraud Exception. Journal of International Banking Law and Regulation, 2014, vol. 29, no. 4, pp. 229-238; HOOLEY, Richard. Fraud and Letters of Credit: Is there a Nullity Exception? The 
credit where he is not entitled to do so is also recognized as an exception to the principle of autonomy in some jurisdiction ${ }^{18}$. Following chapters will analyse legal potentials imposed by express restrictions on beneficiary to draw on the credit in the framework of underlying contact as a potential exception to principle of autonomy and its effect on LC transaction in different jurisdictions.

\section{Nature of exception}

As it is already discussed, operation of the letter of credit is based on two fundamental principles of autonomy and strict compliance. Principle of autonomy separates the credit (or bank guarantee) from underlying contract. ${ }^{19}$ At the same time principle of strict compliance provides beneficiary with right to draw on the credit (or bank guarantee) by presenting complying documents to bank ${ }^{20}$. In such situation, applicant would be rightly concerned about possibility to face with beneficiary's fraud or unconscionable conduct while it is almost impossible to stop bank from payment against complying presentation. Therefore, he might look for further alternatives to safeguard his economic interests. A practical solution can be including restrictive clause against drawing right of beneficiary in underlying contract. Different reasons might stand behind agreement of beneficiary with such restrictive clauses including: higher bargaining power of buyer, need for building trust with buyer and also applying such negative covenants instead of assuming costs of counter guarantee.

\section{Approach of different Jurisdictions}

\subsection{England}

Review of relevant authorities reviles the fact that English law does not have any clear stance regarding the exception ${ }^{21}$. The fact is that no English case has rejected possibility to grant injunctive relief against beneficiary who has called for drawing on the credit in contrary to his commitment under the contract for not doing so. At the same time, there is no authority which agrees with granting injunction to restrain beneficiary to an instrument (the commercial documentary letter of credit or demand guarantee) on the basis of violation beneficiary's obligations in underlying contract. However, approach of English courts in recent cases show positive tendency towards recognition of the exception.

Cambridge Law Journal, 2002, vol. 61, no. 2, pp. 239-294.

18 ALAVI, Hamed . Comparative study of Unconscionability exception to the principle of autonomy in law of Letter of Credits. Acta Universitatis Danubius. Juridica, 2016, vol. 12, no. 2, pp. 94-121.

19 Article 4 \&5 UCP 600

20 ALAVI . Hamed. Illegality as an exception to principle of autonomy in Documentary Letters of Credit; A comparative approach, Korea University Law Review, 2016, vol. 20, p. 3.

21 ENONCHONG, Nelson. The Independence Principle of Letters of Credits and Demand Guarantees. Oxford: Oxford University Press, 2011, p. 100. 


\subsubsection{Early Cases}

The case of RD Harbottle (Mercantile) v National Westminster Bank $k^{22}$ touched upon possibility of granting injunction against beneficiary who demands payment under the demand guarantee by violating provisions regulating such demand in underlying contract. In that case, dispute arose among parties regarding the quality of goods supplied and buyer (Beneficiary to the guarantee) requested payment under the demand guarantee provided by seller in support of his commitments within the framework of underlying contract. Buyer made the demand by neglecting respective procedural provisions for demand in the underling contract. Account party to the guarantee applied for an injunction on the ground that demand of beneficiary is qualified to meeting provisions of underlying contract ${ }^{23}$. In the hearing, Kerr J. observed: "the plaintiffs may well be right in contending that the buyers have no contractual right to payment of any part, let alone the whole, of the guarantee... But all these issues turn on contractual disputes" ${ }^{24}$. While rejecting to grant injunction, he argued: in absence of fraud, court will not interfere and let parties to settle relevant dispute either by litigation of arbitration as available to them. ${ }^{25}$

In Themehelp Ltd $v$ West and Others ${ }^{26}$, at trial court, injunction was granted against beneficiary on the basis of fraud. However, in The Court of Appeal, Waite $J$, changed the position as it was claimed that beneficiary's call to draw on the credit was violating underlying contract. He held: "I do not find it necessary to consider whether the principle extends beyond instances of fraud to cases where the beneficiary under the guarantee is alleged to be in non-fraudulent breach of the main contract"27.

\subsubsection{Recent approach}

In more recent case of Sirius Insurance International Ltd $v$ FAI General Insurance ${ }^{28}$ issue was discussed again. In this case where a Lloyd's syndicate (Agnew) intended to reinsure her liabilities, FAI General Insurance was proposed for this purpose. Not being happy with solvency issues of FAI, Agnew searched for more solid reinsurance company. As a result, Sirius International was chosen where it agreed to make payments to Agnew upon requests and then receive the reimbursement from FAI. In fronting FAI's agreement with Agnew, Sirius asked for a letter of credit to support its payment obligations in underlying contract with FAI and agreed not to draw on the credit until certain conditions are met. Where the problems arose, the Court of Appeal unanimously rejected Sirius's conten-

22 RD Harbottle (Mercantile) $v$ National Westminster Bank [1978] QB 146.

23 Ibid

24 Ibid 155

25 Ibid 156

26 Themehelp Ltd $v$ West and Others [1996] QB 84

27 Ibid 99

28 Sirius Insurance International Ltd v FAI General Insurance [2003] 1 WLR 87. 
tion that with reference to autonomy principle he is entitled to draw on the credit upon presentation of confirming documents. The court held that on the facts of the case, it would grant injunction and restrain Sirius from demanding payment under the LC due to its breach of underling contract with FAI. ${ }^{29}$

However, the House of Lords reversed the judgement by holding Sirius eligible to demand under the LC as conditions in underlying contract were met. ${ }^{30}$ Therefore, they did not reach the point whether or not demand of beneficiary under the letter of credit or bank guarantee in breach of his commitment in underlying contract will qualify for granting injunction against him. ${ }^{31}$

In conclusion, English law does not have a clear approach to this problem. However, analysing relevant authorities show development of trend towards recognition of such exception where court will grant injunction against beneficiary whose demand is in breach of contract with third party.

\subsubsection{Scope of the Exception.}

According to existing authorities in English Law, underlying contract exception might find application in limited number of occasions: Firstly, exception can apply only in case of existence of a negative covenant made by beneficiary in underlying contract. Secondly, it applies only where negative covenant is given in express terms. In contrary with Australian courts which grant injunction in presence of both implied and express negative covenant, English law does not consider implied terms as a ground for granting injunction. ${ }^{32}$ Thirdly, exception only applies in cases of granting injunction against beneficiary's demand to draw on letter of credit. It does not prevent bank from effecting payment after receiving complying presentation. Finally, bank cannot use existing negative covenant of beneficiary in underlying contract as a ground to stop payment after receiving the complying presentation.

\subsubsection{Negative Covenant.}

Legal basis for granting injunction in presence of negative covenant under English law is decision of court in Lumley $v$ Wagner $^{33}$ and Doherty $v$ Allman ${ }^{34}$ where the court considered existence of negative covenant of beneficiary in contract as a ground for enjoining him. The Court of Appeal in Sirius Insurance International Ltd $v$ FAI General Insurance with reference to decision of the House of Lords in Doherty v Allman and its well-respected implication in English Law

29 Ibid 29

30 [2004] UKHL 54

31 ENONCHONG, Nelson. The Independence Principle of Letters of Credits and Demand Guarantees. Oxford: Oxford University Press, 2011, p. 213.

32 Ibid 214

33 Lumley $v$ Wagner (1852) 1 De, GM \& G 604

34 Doherty v Allman (1877-78) LR 3 App Case 709 
considered restriction on beneficiary's right to draw on the credit to be grated due to his negative covenant in underling contract. ${ }^{35}$ Therefore, May LJ held: "There is no authority extending this autonomy of documentary credit for the benefit of the beneficiary of letter of credit so as to entitle him as against the applicant to draw the letter of credit when he is expressly not entitled to do so"36.

\subsubsection{Presence of express term.}

Under English law, where there is no express term in underlying contract which limits entitlement of beneficiary to draw on letter of credit or demand guarantee, it will be fairly impossible for court to issue injunction and uphold the exception to prevent beneficiary from receiving payment. ${ }^{37}$ In case of Deutsche Ruckversicherung Aktiengeslleschaft $v$ Walbrook Insurance Co $l t d{ }^{38}$, Phillips J considered it wrong to "imply a term into the underlying contract that the beneficiary will not draw on the letter of credit unless payment under the underlying contract is due" ${ }^{39}$. In the case of Sirius, existence of the express term which was restriction of beneficiaries right to be paid upon realization of particular situation, made the Court of Appeal to consider the contract as "unusual"40 or "variant of more typical case" ${ }^{\text {"41 }}$. With reference to restriction expressly mentioned in underlying contract, court considered the letter of credit in that case as "less than equivalent of cash" and eligible for granting an injunction to restrain beneficiary. ${ }^{42}$ However, as it will be discussed later, Australian courts fully recognize the exception. However, they consider implied restrictions imposed on beneficiary within the framework of underlying contract in addition to express ones as a ground for granting injunction against him.

35 in Doherty v Allman Lord Cairns, with respect to a negative covenant and the basis of which it could be used to grant an injunction, justified its rationale by stating thus:

"if there had been a negative covenant, I apprehend, according to well-settled practice, a Court would have had no discretion to exercise. If parties, for valuable consideration, with their eyes open, contract that a particular thing shall not be done, all that a Court has to do is to say, by way of injunction, that which the parties have already said by way of covenant, that the thing shall not be done; and in such case the injunction does nothing more than give the sanction of the process of the Court to that which already is the contract between the parties. It is not then a question of the balance of convenience or inconvenience, or of the amount of damage or of injury- it is the specific performance, by the Court, of that negative bargain which the parties have made, with their eyes open, between themselves".

36 Sirius International Insurance Corp v FAI General Insurance Co Ltd [2003] EWCA Civ 470 [2003], 1 WLR 2214, 2224-25.

37 ENONCHONG, Nelson. The Independence Principle of Letters of Credits and Demand Guarantees. Oxford: Oxford University Press, 2011, p. 214.

38 Deutsche Ruckversicherung Aktiengeslleschaft $v$ Walbrook Insurance Co ltd [1995] IWLR 1017, [1995] 1 Lloyd's Rep 153.

39 Ibid at 1030

40 [2003] 1 WLR 87,91. At 30

41 Ibid at 27

42 Ibid 


\subsubsection{Non availability of exception against the bank.}

The pool of authorities shows that underlying contract exception would be only applicable to beneficiary who is party to underlying contract and no one else. Therefore, it is impossible to rely on beneficiary's breach of the underlying contract to grant injunction against bank and restrain it from payment under the credit if it wishes to do so. This would be a serious limitation on applicability of the exception as even obtaining injunction against beneficiary might not prevent him from being paid by bank. In Bolivinter Oil SA $v$ Chase Manhattan Bank, ${ }^{43}$ within the framework of underlying contract of affreighement, Boliventer agreed to take a certain cargo of oil from Iran to Syria and deliver it to the General Company Homs Refinery. According to the terms of contract, Boliventer opened a demand guarantee in favour of Homes which issued by Commercial Bank of Syria (CBS) after receiving instructions form Chase Manhattan Bank. In return CBS issues an irrevocable documentary letter of credit in favour of Chase Manhattan. Despite arising disputes between parties to the contract of affreightment, they entered into a second contract based on similar terms but different amount of cargo to be delivered. According to Boliventer, parties agreed to release the guarantee after reaching the final shipment of cargo from second contract to Syria. Homes claimed such agreement was under duress and claimed for payment of guarantee after receiving final shipment. In an ex parte action, Boliventer managed to get injunction for restraining CBS to pay beneficiary, Chase bank to paym CBS, and beneficiary from receiving payment under the guarantee. ${ }^{44}$ During the hearing, Staughton J. lifted injunction against banks but emphasized on continuation of injunction against Homes (the beneficiary). While ruling in favour of plaintiffs, judge concluded that existence of agreement to release the guarantee at the end of second contract is sufficient to prove fraudulent action by Homes. Ruling was upheld by The Court of Appeal. ${ }^{45}$

\subsubsection{Bank cannot rely of exception as a defence for payment.}

The exception is only available for parties to the contract under which beneficiary has been restrained from drawing on the instrument. As a result, bank cannot rely on the exception as it is not originally a party to the underlying contract which is reason for issuing the letter of credit. In English law, legal basis to preclude issuing bank from using exception as defence for payment against beneficiary lies in Doctrine of the Privity of Contract ${ }^{46}$.

43 Bolivinter Oil SA v Chase Manhattan Bank [1984] 1 Lloyd's Rep 251.

44 Ibid

45 Ibid 257

46 "The doctrine of privity means that a contract cannot, as a general rule, confer rights or impose obligations arising under it on any person except the parties to it." In TREITEL, G.

H.. The law of contract. London: Sweet \& Maxwell, 2003. 


\subsubsection{Standard of Proof}

In accordance with fraud exception, it seems that standard of proof at trial stage should be establishing the fact that beneficiary's demand is in breach of an express term in underlying contract between parties. ${ }^{47}$ With the same analogy, at the interlocutory stage in might be presumed that standard of proof for granting injunction should be in favour of existence of a seriously arguable case. ${ }^{48}$ However, The Court of Appeal in Sirius granted injection because in addition to existence of seriously arguable case, applicants established that beneficiary is trying to draw payment on the credit in breach of underlying contract. ${ }^{49}$ Later, in case of Permasteelisa Japan KK v. Bouyguesstroi ${ }^{50}$ which was concerned with a performance bond, decision of Sirius was interpreted as requirement for higher standard of "positively established" case.

However, according to Enonchong, there is no possibility to conclude that required standard of "positively established case" was introduced by The Court of Appel of Serious. ${ }^{51}$ He further argues that The Court of Appeal in that particular case mentioned applicant has not only met the standard of "seriously arguable" case but also provided evidence which "positively established" nonentitlement of beneficiary to draw under the credit. ${ }^{52}$ Therefore, by referencing to standard of "positively established" case, The Court of Appel was merely making decision about the fact of case in hand rather than laying down a general standard of proof.

Enonchong also introduces two main advantages of his interpretation from statement of The Court of Appeal: first is that in accordance with required standard of proof in fraud, "underlying contact exception" keeps the same lower standard of "seriously arguable case" for interlocutory stage and standard of "positively established" case for trial. Second, such approach will keep the standard of proof in English law synchronized with other jurisdictions (as it will be discussed in next part, Australia has also accepted the "seriously arguable case" as standard of proof for interlocutory stage)..$^{53}$

\subsection{Australia}

Australian cases show positive approach to establish contractual restrictions on beneficiary for drawing down on credit as an exception to the principle of

47 ENONCHONG, Nelson. The Independence Principle of Letters of Credits and Demand Guarantees. Oxford: Oxford University Press, 2011, p. 217.

48 Ibid

49 [2003] 1 WLR 87,91. At30

50 Permasteelisa Japan KK v. Bouyguesstroi [2007] EWHC 3508

51 ENONCHONG, Nelson. The Independence Principle of Letters of Credits and Demand Guarantees. Oxford: Oxford University Press, 2011, p. 217.

52 Ibid

53 Ibid 
autonomy. Although most cases are relevant to bank guarantees, but it is possible to say that except High Court of Australia, other courts are of the position that: "there is an exception to the principle of autonomy where there is an underlying contract between the applicant for the guarantee and the beneficiary which restricts the beneficiary's power to demand payment under the guarantee" ${ }^{\prime 54}$.

Pearson Bridge Pty Ltd $v$ State Rail Authority of New South Wales ${ }^{55}$ is among earliest and most prominent cases in this regard. In Pearson case, article 15.5 of underlying contract of construction between parties provided necessary security for performance of contract. ${ }^{56}$ Yeldham J, considered the clause as negative covenant which provides definition of circumstances under which beneficiary can demand payment under the guarantee and issued injunction against beneficiary on the ground that demand of beneficiary in presence of negative stipulation in the underlying contract was a serious issue to be tried ${ }^{57}$. While making decision, court refed to other Australian cases in supporting its conclusion ${ }^{58}$.

Wood Hall Ltd $v$ Pipeline Authority ${ }^{59}$ is often cited Australian case in regard with underlying contract exception. In this case, an unqualified guarantee was issued in favour of beneficiary for the purpose of constructing a pipeline. Upon demand of beneficiary to draw on the guarantee, applicant claimed that beneficiary cannot demand payment under guarantee as they (applicants) were not in breach of underlying contract. The High Court of Australia while ruling in favour of beneficiary held that it was not possible to stop payment claimed under the guarantee in presence of unqualified conditions obliging bank to pay unconditionally against such claim. ${ }^{60}$

There are considerable similarities between ways in which exception is recognized and applied under English and Australian law. First, exception in both jurisdictions will be applicable only in presence of express term in underlying contract to restrict beneficiary from claiming payment under the LC or bank guarantee before realization of certain circumstances.

54 Clough Engineering limited $v$ Oil and Gas Corporation Limited [2008] FCAFC 136.

55 Pearson Bridge Pty Ltd $v$ State Rail Authority of New South Wales (1982) 1 Aust. Construction LR 81.

56 "if the principles becomes entitled to exercise all or ant of his rights under the contract in respect of the security, the principle may convert into money the security that does not consist of money. The principle shall not be liable for any loss occasioned by such conversions."

57 ENONCHONG, Nelson. The Independence Principle of Letters of Credits and Demand Guarantees. Oxford: Oxford University Press, 2011, p. 219.

58 Williamson Limited $v$ Lukey and Mulholland (1931) 45 CLR 282, 299; Ampol Petroleum Limited v Mutton (1952) 53 SR1

59 Wood Hall Ltd v Pipeline Authority (1979) 141 CLR 443

60 ENONCHONG, Nelson. The Independence Principle of Letters of Credits and Demand Guarantees. Oxford: Oxford University Press, 2011, p. 219. 
Second, such express term in both jurisdictions is recognized only if it shows the format of negative covenant. Third, exception is only applicable against beneficiary's demand and it cannot be used for stopping bank from payment. In both jurisdictions, restriction cannot be used as a defence by bank to refrain payment under documentary letter of credit or bank guarantee.

Despite similarities between the way in which Australian and English courts apply the exception, there are certain differences between their approaches which are worth of attention: Firstly, in contrary with English practice, many Australian cases consider the scope of exception extended to implied terms in addition to express negative covenants in the underlying contract ${ }^{61}$. Secondly, early cases in Australia adopted the low standard of proof of "a serious issue to be tried" for granting interim injunction against beneficiary whose claim was not in accordance with negative covenant in underlying contract. ${ }^{62}$ Recent cases show the trend of among courts for adopting higher standard of "seriously arguable" case under which applicant should be able to show at trial that demand was in breach of conditions stipulated in underlying contract ${ }^{63}$. English courts apply a much higher standard of "positively established case" which creates difficulties for applicant to attain injunction against beneficiary on the basis of underlying contract exception.

Thirdly, in Australia applicant should provide court with evidence of facing loss as a result of beneficiary's demand in contrary to his commitments in underling contract to be able to obtain interim injunction. Such evidence is provided through application of the balance of convenience mechanism ${ }^{64}$. However, balance of convenience has very limited application under English Law. Therefore, in England applicant may obtain injunction against beneficiary by satisfying the standard of proof and without showing any loss which is in contrary with Australian position in which obtaining injunction after satisfying the standard of proof would be possible only by showing damages endured as result of beneficiary's demand . ${ }^{65}$

61 Australian Winch and Haulage Co Pty Ltd v. Walter Construction Group Ltd [2002] FCA 1181 ; Reed Construction Services Pty Ltd v. Kheng Seng (Australia) Pty Ltd (1999) 15 BCL 158 ; Fletcher Construction Australia Ltd v. Varnsdorf Pty Ltd [1998] 3 VR 812

62 Pearson Bridge Pty Ltd $v$ State Rail Authority of New South Wales (1982) 1 Aust. Construction LR 81; Selvas Pty Ltd v Hansen \& Yuncken (S.A.) Pty Ltd (1987) 6 ACLR 36.; J H Evans Industries (NT) Pty Ltd v Diano Nominees Pty Ltd (unreported NT Supreme Court, 30 January 1989); Barclay Mowlem Construction Ltd $v$ Simon Engineering (Australia) Pty Ltd (1991) 23 NSWLR 451.

63 Rejan Constructions Pty Ltd v. Manningham Medical Center Pty Ltd ( Supreme Court of Victoria , 20 December 2002 , Byrne J) .

64 ENONCHONG, Nelson. The Independence Principle of Letters of Credits and Demand Guarantees. Oxford: Oxford University Press, 2011, p. 221.

65 Ibid 
In conclusion, more extended scope of exception in Australia which includes implied terms in the contract between applicant and beneficiary and lower standard of proof are adjusted by application of balance of convenience test and requiring applicant to show damages which he will bear in absence of injection. The same adjustment has been achieved by English courts via counterbalancing a higher standard of proof and more limited scope of exception with no application of the balance of convenience test.

\subsection{Scotland}

In the case of Peak Well Management Ltd v. Globalsaltafe Drilling UK Ltd ${ }^{66}$ under a contract between parties, beneficiary (Globalsaltafe) agreed to supply a mobile drilling rig to applicant (Peak Well Management) and applicant provided beneficiary with a standby letter of credit. After arising problems between parties, applicant required court to issue an interdict and prevent beneficiary from demanding under the credit based on rational that in the underlying contract parties agreed that demand to draw on the credit will be fulfilled only in respect of unpaid invoices that did not receive notice of payment by account party. In hearing, beneficiary argued that in absence of fraud, account party has no right to interfere with autonomy principle of documentary letters of credit ${ }^{67}$. While rejecting the contention of beneficiary, court held that entitlement of beneficiary to draw on the credit depends on terms of underlying contract. Therefore, the court held that demand is in breach of underlying contract and issued the interdict against beneficiary. ${ }^{68}$

\subsection{Malaysia}

In similar vein with Australian courts, Malaysia courts to have a settled approach towards contractual restrictions imposed on beneficiary to draw on the credit. In Daewoo Engineering \& Construction Co Ltd $v$ The Titular Roman Catholic Archbishop of Kuala Lumpur ${ }^{69}$ claimant opened a guarantee in favour of defendant for the purpose of getting his consent in order to install ground anchors in his land. Within the underlying contract for opening the guarantee, it was clearly mentioned that defendant's right to draw on the guarantee, among other things, will be subjected to : "must inform Daewoo Corporation by written notice of your intention to claim against the guarantee not later than 14 (fourteen) days before the date of the aforesaid demand"70. After expiration of agreement, parties agreed to renew it . However, defendant insisted on removal of the express term in underlying contract which was rejected by plaintiffs.

66 Peak Well Management Ltd v. Globalsaltafe Drilling UK Ltd[2006] Scot SC3

67 Ibid 24

68 Ibid

69 Daewoo Engineering \& Construction Co Ltd v The Titular Roman Catholic Archbishop of Kuala Lumpur [2004] 7 MLJ 136.

70 Ibid 18 
Finally, plaintiff failed to renew the agreement due to insisting of the defendant to remove the express restrictions relevant to call on guarantee, defendants made the call for it and argued that bank guarantee is separated from underlying contract and not subjected to any restriction imposed by it. During the hearing, injunction was granted in favour of the plaintiff on the ground of existence of serious issues to be tried. ${ }^{71}$

According to the case of Daewoo Engineering \& Construction Co Ltd $v$ The Titular Roman Catholic Archbishop of Kuala Lumpur it is possible to conclude that existence of express contractual agreement between beneficiary and account party of letters of credit and independent guarantees which imposes restriction on beneficiary's right of unconditional drawing on the instrument is recognized as an exception to principle of autonomy by Malaysian courts.

\subsection{Singapore}

Singaporean courts have not touched upon this problem directly. However, in respective cases of fraud and unconscionable conduct where injunction has been granted against the beneficiary, main claim raised by account party attributed to beneficiary's non-entitlement to draw on the credit as condition precedent for payment mentioned in underlying contract was not fulfilled. In Kvaerner Singapore Plc Ltd $v$ UDL Shipbuilding (Singapore) Ltd ${ }^{72}$ contract of sales covered sales of equipment and supported by performance bond of beneficiary under the condition in which buyer provides sales price via opening a documentary letter of credit. After failure of buyer in opening the credit, court granted inunction restraining buyer from drawing under performance bond as he could not fulfil the condition precedent stipulated in the underlying contract ${ }^{73}$. Further, court mentioned that buyer's conduct was considered as unconscionable conduct due to lacking good faith. ${ }^{74}$

In conclusion, the underlying contract exception has been touched upon by Singaporean courts. However, it is not clear from the details of the case law whether or not court will grant restraining order against beneficiary in absence of fraud and unconscionable conduct only on the basis of beneficiary's breach of his commitment in underlying contract.

\subsection{United States of America}

Under Uniform Commercial Code, there is no injunction available against beneficiary's demand to draw on the credit in breach of his commitments within underlying contract with applicant. According to Article 5-110 (2) of UCC : " if it presentation is honoured, the beneficiary warrants ... to the [account party]

71 Ibid 25

72 Kvaerner Singapore Plc Ltd v UDL Shipbuilding (Singapore) Ltd [1993] 3 SLR 350

73 Ibid

74 Ibid 
that the drawing does not violate any agreement between the [account party] and the beneficiary or any other agreement intended by them to be augmented by the letter of credit". The only caveat to above mentioned passages is that it only works where presentation made by beneficiary is honoured. Paragraph 1 of the official commentary on UCC clarifies that bank cannot rely on beneficiary's breach of warranty with applicant to refuse payment. In the same way, applicant cannot rely on beneficiary's breach of his commitments in underlying contract to refuse reimbursement of bank. Since warranty can be obtained only after honouring the credit or guarantee, such breach can occur only after effectuating the payment. Therefore, under the UCC, instead of grating injunction, remedy for breach of warrantee is in the format of damages.

\section{Arguments for and against recognition of exception}

Reviewing the exception in different jurisdictions shows diversified approach of courts in different countries to the problem of "underlying contract exception" to principle of autonomy in letter of credit law. While some countries like Australia, Malesia and Singapore have recognized the exception, English courts are taking unsettled position and UCC in the United States of America rejects recognition of any exception to the principle of autonomy other than Fraud. However, in terms of legal policy, there are some arguments in favour of the recognition of exception which balance the contradicting arguments against recognition of it. In this section arguments in favour and against recognition of the exception will are going to be reviewed.

\subsection{Arguments in favour of the recognition of exception}

\subsubsection{Novelty of exception}

The novelty brought about by exception has been discussed by Australian courts like in case of Bachmann Pty Ltd v B.H.P Power New Zealand Ltd ${ }^{75}$. The issue of novelty was restated by Rolf .J in Barclay Mowlem Construction Ltd $v$ Simon Engineering (Australia) Pty $\mathrm{Ltd}^{76}$ when he submitted that :

75 (1999) 1 VR 420. In this case the judge observed:

"...so far as I am aware, of the cases which have come before the courts in this country the present may be said to be novel in one respect and unusual in another. It is novel in the sense that the present case raises for the first time the effect of an express, albeit qualified, contractual prohibition (in the underlying contract) on the conversion of a security into cash. The novelty resides in the circumstance that the present contract contains an express, but qualified, prohibition on conversion of a security into cash - express in the sense that it is in form a negative stipulation ('a party shall not convert ... until the party becomes entitled').

76 Barclay Mowlem Construction Ltd v Simon Engineering (Australia) Pty Ltd (1991) 23 NSWLR 451,457 
"In my opinion neither Wood Hall nor Hortico, nor the various cases to which I was referred stating that there was an obligation on the party giving an unconditional performance bond to pay that bond on demand are determinative of the present case. Indeed in Wood Hall, Stephen J expressly leaves open, so it seems to me, this question for determination"77

To clarify his comments, Rolf J. referenced statement of Stephen J , in Wood Hall : “... Had the construction contract itself contained some qualification upon the Authority's power to make a demand under a performance guarantee, the position might well have been different." ${ }^{\text {7 }}$

In English case of Sirius Insurance International v FAI General Insurance ${ }^{79}$ also pointed at novelty of cases under which beneficiary is facing retractions by underlying contract for purpose of drawing on the credit ${ }^{80}$.

It is possible to conclude that irreversible and express consent of beneficiary in underlying contract for not drawing on credit before meeting some conditions will create a novel condition which turns the cash principle of documentary letters of credit conditional to fulfilment of stipulated conditions.

\subsubsection{Parties expectations from underlying contract}

It can be mentioned with confidence that according to general principles of contract law, enforcement of legitimate expectations of parties in the framework of underling contract is the main concern of contract. In substantial number of cases, under English law and other jurisdictions court has referred to method agreed by parties in underlying contract and surrounding circumstances of the case as the main factor for determining how to resolve their dispute. Therefore, on the occasion where underlying contract gives right to draw on credit to beneficiary after meeting special conditions, the court will look upon the contract and circumstances of the case to define whether or not bank is entitled to effectuate the payment. In the leading English case of Sirius May LJ implied the legiti-

77 Ibid 457

78 Wood Hall Ltd v Pipeline Authority (1979) 141 CLR 443,459 restated in Barclay Mowlem

Construction Ltd v Simon Engineering (Australia) Pty Ltd (1991) 23 NSWLR 451,457.

79 Sirius International Insurance Co v FAI General Insurance Ltd and others [2002] EWHC 1611 (Ch) [2003] 1 WLR 87,.

80 Ibid 92-93, Jacob J. :

"...whilst I accept the submission that the principle of autonomy is of vital importance, I cannot see that it is undermined in the very special case where a party expressly agrees not to draw down unless certain conditions are met. Suppose instead of a letter of credit an account had been opened in the name of Sirius with Westpac and credited with the US $\$ 5 \mathrm{~m}$. Suppose Sirius had agreed with FAI not to touch the account unless the conditions were satisfied. I can see no reason why a contract to that effect should not be enforced. Cash, like a letter of credit, is autonomous, perhaps even more so, but people can agree not to touch identified pots of it, if that is what they want to do. If such an agreement is made, there is no reason why the law should not enforce it'. 
mate expectations of parties from the underlying contract when he refused the augment of the council of defendants. In Sirius International Insurance Co v FAI General Insurance Ltd and others, the council of Sirius was of the opinion that with reference to autonomy principle, he is entitled to draw on the credit even in presence of negative covenant in underlying contract which clearly defines situation to draw dawn on the credit.

\subsubsection{Existence of the negative covenant and its restrictive nature}

According to the Court of First Instance and the Court of Appeal of Sirius, negative covenant by beneficiary in underling contract is the main reason to restrain his right to draw down on the credit. As it was discussed before, the court of Doherty $v$ Allman ${ }^{81}$, as a leading authority in negative covenant explains that court has almost no discretion over the negative covenant which expressly restricts rights of the party under the contract.

\subsubsection{Lack of authority against the recognition of exception}

In the case of the Sirius, The Court of Appeal as well as the Supreme Court admitted that there is no authority against accepting the "underlying contract exception". The court admitted that none of the cases referred to are against accepting the exception. Further the court observed: "express provision in the underlying contract saying that the beneficiary will not draw down unless conditions have been fulfilled. In those circumstances, you do not have the normal case of 'pay first, argues later', which is the main point of providing letters of credit in normal circumstances" 82 . To state it differently, with reference to absence of authority against recognition of underling contract exception, the court did not observe any problem in recognizing capability of express contractual restriction in the underlying contract to be a defence against principle of autonomy.

\subsection{Arguments against recognition of the exception}

\subsubsection{Acting against the age long principle of autonomy}

The often cited argument against recognition of "underlying contract exception" is alleged contradiction of the exception with principle of autonomy in documentary letters of credit. As it was argued in the Court of First Instance in case of Sirius, letters of credit are independent undertakings of bank not affected by the conditions stipulated in the underlying contract. Since the remedy for breach of underling contract is determined in terms of damages, therefore, beneficiary cannot be prevented from drawing dawn on credit on credit based on terms of underlying contract. While responding to appellant's contention, Jacob J, started his argument with reference to importance of the autonomy principle. However,

81 (1877-78) LR 3 App Cas 709.

82 [2002] EWHC 1611 (Ch) [2003] 1 WLR 87,92 [18] 
he continued, it is not clear to him that principle of autonomy would be undermined where beneficiary expressly agrees that before realization of certain circumstances; he would not draw on the credit. ${ }^{83}$

\subsubsection{Creation of uncertainty}

The argument of promoting uncertainty by recognition of exception has been favoured in Australian cases. ${ }^{84}$ Argument raises the question that meaning to expressed terms in the underlying contract might be construed in different ways resulting in different outcomes and creating uncertainty over situation under which injunction should be granted or not. ${ }^{85}$ Such uncertainty might result in reducing the popularity of documentary letters of credits in international trade and create policy concerns. ${ }^{86}$ However, according to Enonchong , problem of uncertainty shall overcome by applying the exception only in presence of express contractual terms which agreed upon openly by consent of both parties. Under such express term, parties agree that beneficiary's right to draw on the credit is qualified to meeting condition of restrictive conditions mentions in the contract. ${ }^{87}$

\section{Conclusion}

This paper tried to study of legal issues surrounding effects of including a restrictive clause on beneficiary's right to draw down on the documentary letter of credit in the underlying contract between buyer and seller in the course of international trade. Despite the fact that it might seem against application of autonomy principle, recognition "underlying contract exception" in Australasia, Scotland and Malaysia plus positive approach of English courts towards it seems to be a signal for readiness of global society to set aside traditional restrictive approach to principle of autonomy in documentary letters of credit. However, regarding the underlying contract exception, there are significant issues which should be resolved, namely, lack of certainty which exist in diversified approach of different jurisdictions to standard of proof. Particularly, acceptance of implied consent of beneficiary as a negative covenant in Australia might result is subjective approach of the court and promotion of uncertainty which in turn can reduce turnout of international trade society to documentary letters of credit at global stage.

However, courage of courts to consider restrictive conditions on beneficiary within the framework of under lying contract to be paid under the credit a signif-

83 Ibid, 19

84 Bachmann Pty Ltd v BHP Power New Zealand Ltd [1999] 1 V R 420, Fletcher Construction Australia Ltd $v$ Varnsdorf Pty Ltd [1998] 3 VR 812.

85 [1999] 1 V R 420

86 ENONCHONG, Nelson. The Independence Principle of Letters of Credits and Demand Guarantees. Oxford: Oxford University Press, 2011, p. 266.

87 ENONCHONG, Nelson.. The Problem of Abusive Drawing on Demand Guarantees. Lloyd's Maritime and Commercial Law Quarterly, 2007, p. 96. 
icant issue to be tried is an important development in international commercial law. Such development will be more considerable as recognition of such exception will turn cash nature of documentary letters of credit and bank guarantees in to a conditional instrument under which receiving the payment by beneficiary will depend on fulfilment of his obligations in the underling contract. Therefore, it is not clearly possible for a beneficiary to a documentary letter of credit or bank guarantee to rely on freedom of contract to commit whatever possible obligation in the contract with applicant and then neglect fulfilment of those obligations with reference to autonomy principle and separation of the credit form underlying contract. 